\title{
Dietrich von Hildebrand: Konteksty pedagogiczne kategorii wartości i cnoty
}

Dietrich von Hildebrand: Pedagogical Contex† of Value and Virtue Category

\begin{abstract}
ABSTRAKT
Artykuł ma celu wydobycie pedagogicznych implikacji z koncepcji wartości oraz komplementarnego wobec niej poięcia cnoty w ujęciu Dietricha von Hildebranda. W pierwszej części artykułu zarysowana została szeroka panorama dorobku Hildebranda. W drugiej - omówiono jego koncepcję wartości w kontekście tradycji realistycznej fenomenologii. Trzecia część wskazuje na sferę cnót jako niezbywalny obszar realizacji wartości moralnych. W części czwartej postulowana jest zależność koncepcji wychowania od założeń antropologiczno-etycznych. W tej perspektywie z Hildebrandowskich koncepcji wartości i cnoty wynikaja wysokie wymagania pod adresem wychowawców.
\end{abstract}

\section{ABSTRACT}

The aim of the article is to extract the pedagogical implications of the concept of values and the complementary notion of virtue as conceived by Dietrich von Hildebrand. The first part presents a wide panorama of Hildebrand's ovevre. The second discusses his concept of value in the context of the tradition of Realist Phenomenology. The

Articles and dissertations
SLOWA KLUCZOWE

wartość, cnota, wychowanie moralne, Dietrich von Hildebrand, fenomenologia realistyczna

KEYWORDS

value, virtue, moral education, Dietrich von Hildebrand, realist phenomenology

SPI Vol. 19, 2016/1

ISSN 2450-5358

e-ISSN 2450-5366

DOI: 10.12775/SPI.2016.1.005

Artykuły i rozprawy 
third identifies the realm of virtues as an inalienable area of the implementation of moral values. The fourth postulates the dependence of the concept of education on the anthropological and ethical assumptions. In this perspective, the Hildebrandian concepts of values and virtues place high demands on educators.

\section{Wstęp}

Niniejszy artykuł jest próbą aplikacji fenomenologicznej etyki wartości, w wersji wypracowanej przez Dietricha von Hildebranda, do dziedziny edukacji. Hildebrand rozwija oryginalną teorię na temat istnienia i statusu wartości, w tym zwłaszcza wartości moralnych. Od strony podmiotowej odpowiedź na wartość związana jest z pojęciem cnoty, którą Hildebrand stawiał w centrum swojej koncepcji etycznej zanim jeszcze nastąpił współczesny renesans neoarystotelesowskiej etyki cnoty. Zestawienie znaczenia tych dwóch pojęć niesie znaczące implikacje dla teorii wychowania moralnego i, jak sądzę, może pozwolić w świeży sposób spojrzeć na etyczny wymiar edukacji ${ }^{1}$.

\section{Twórczość Hildebranda}

Dietrich von Hildebrand był przede wszystkim filozofem i jego najważniejsze książki są dziełami filozoficznymi. Oprócz tego był również płodnym autorem książek i artykułów o tematyce religijnej, co wynikało z głęboko przeżytego przez niego nawrócenia w początkach dorosłego życia. Przy tym sferę życia nadprzyrodzonego opisywał przy użyciu kategorii filozoficznych, natomiast jego teksty filozoficzne noszą silne piętno jego wiary. Na tych dwóch głównych filarach jego życia i twórczości opierała się także antynazistowska publicystyka polityczna, którą uprawiał głównie na łamach czasopisma „Der Christliche Ständestaat”. Poniższa kategoryzacja nie

1 O pewnym renesansie zainteresowania aksjologią pedagogiczną może świadczyć temat IX Ogólnopolskiego Zjazdu Pedagogicznego: Ku życiu wartościowemu. Idee - koncepcje - praktyki. Także sama koncepcja Hildebranda była już przedmiotem rozważań pedagogów, jakkolwiek na dość dużym poziomie ogólności: por. np. A. Molesztak, A. Tchorzewski, W. Wołoszyn, $W$ kręgu wartości moralnych nauczyciela, Warszawa 1996, s. 15-16, 55-56. 
powinna zatem przysłaniać niezwykłej spójności, cechującej całość jego pisarskiej spuścizny.

Twórczość filozoficzną Hildebranda otwiera praca doktorska, zatytułowana Die Idee der Sittlichen Handlung (Idea dziatania moralnego), bardzo wysoko oceniona przez Edmunda Husserla i opublikowana w 1916 roku w trzecim tomie "Jahrbuch für Philosophie und phänomenologische Forschung”. Kolejnym dziełem, opublikowanym w roku 1922 w piątym tomie tegoż czasopisma, była praca habilitacyjna Sittlichkeit und ethische Werterkentnis (Moralność i etyczne poznanie wartości). W 1930 roku opublikował Die Metaphysik der Gemeinschaft, która, choć była książką ściśle filozoficzną, dała teoretyczne podstawy jego późniejszej antytotalitarnej publicystyce (polski przekład Metafizyka wspólnoty, 2012). W 1932 roku opublikował zbiór wykładów i rozpraw Zeitliches im Lichte des Ewigen (Doczesnośc w świetle wieczności). W 1933 roku ukazały się Sittliche Grundhaltungen, przetlumaczone na język angielski w roku 1950 jako Fundamental Moral Attitudes, a po polsku jako Fundamentalne postawy moralne (Wobec wartości, 1982), których rozbudowaną wersją była The Art of Living (wraz z Alice von Hildebrand, 1965), przetłumaczona także na polski jako Sztuka życia (2002). Po wojnie w 1950 roku ukazała się Der Sinn philosophischen Fragens und Erkennens (Istota badania i poznania flozoficznego), pierwowzór późniejszej wersji angielskiej What is Philosophy? (1960), przetłumaczonej następnie m.in. na niemiecki (Was ist Philosophie? [1960], a później jako pierwszy tom serii Gesammelte Werke [1976]), a także na polski Czym jest filozofia? (2012). Najważniejsze późniejsze dzieła to: Christian Ethics (1953, w j. niemieckim jako Christliche Ethik [1959], drugie wydanie zatytułowane: Ethics [1972]), Die Menscheit am Scheideweg (1955 - zbiór rozpraw i artykułów rozszerzony w stosunku do Zeitliches im Lichte des Ewigen), True Morality and Its Counterfeits (1955 - drugie wydanie pod tytułem Morality and Situation Ethics, 1966), Graven Images: Substitutes for True Morality (1957), Man and Woman (1966), Das Wesen der Liebe (1971, w j. angielskim: Nature of Love, [2009]), Ästhetik, t. 1 (1977), Moralia (1980), Ästhetik, t. 2 (1984).

Także pisarstwo religijne Hildebranda było przesiąknięte duchem jego filozofii. Jako pierwszą należy tu wskazać wydaną w 1927 roku książkę Reinheit und Jungfräulichkeit, której tematem była analiza katolickiego rozumienia ideału czystości i dziewictwa. Kolejna, zatytu- 
łowana Die Ehe (Matżeństwo), została opublikowana w roku 1929. W 1931 roku ukazała się praca Das Katholische Berufsethos (Katolicki etos zawodowy), a w roku 1933 Liturgie und Persönlichkeit, niedawno wydana $\mathrm{w}$ języku polskim pod tytułem Liturgia $i$ osobowość (2014).W 1940 roku Hildebrand pod pseudonimem Peter Ott wydał książkę Die Umgestaltung in Christus... Über Christliche Grundhaltung (w j. polskim: Przemienienie w Chrystusie [1982]). Dzieła powojenne: The New Tower of Babel (1954), The Sacred Heart. An Analysis of Human and Divine Affectivity (1965, w j. polskim: Serce: rozważania o uczuciowości ludzkiej i uczuciowości Boga-Cztowieka [1985]), Trojan Horse in the City of God (1967, w j. polskim: Kon trojański w Mieście Boga [2006]), Die Enzyklika "Humanae Vitae” ein Zeichen des Widerspruchs (1968), Zölibat und Glaubenskrise (1970), Der verwüstete Weinberg (1973, w j. polskim: Spustoszona winnica [2006]).

Publicystykę polityczną Hildebranda, w której wyartykułował on swoją wizję ratunku cywilizacji zachodniej przed nazizmem, otwiera artykuł w „Reichspost” w 1933 roku, zatytułowany Österreichs grosse deutsche Stunde. W latach 1933-1938 Hildebrand redagował czasopismo „Der Christliche Ständestaat”, w którym opublikował w sumie 77 artykułów. W 1934 roku napisał pośmiertną biografię kanclerza Engelberta Dollfussa, zatytułowaną Engelbert Dollfuss. Ein katholisher Staatsman. Ważnym artykułem, zamieszczonym w roku 1937 w piśmie „Die Erfüllung”, był tekst Die Juden und das Christliche Abendland, który zawierał krytykę antysemityzmu.

Myśl Hildebranda nie traci do tej pory na aktualności, o czym świadczą pojawiające się wciąż nowe tłumaczenia jego dzieł, nowe wydania, a także obszerna i stale powiększająca się literatura sekundarna. Najważniejszym ośrodkiem w tym względzie jest amerykańska fundacja The Hildebrand Project ${ }^{2}$, staraniem której ukazało się thumaczenie The Nature of Love oraz anglojęzyczna edycja antynazistowskiej publicystyki Hildebranda My Battle Against Hitler Faith, Truth, and Defiance in the Shadow of the Third Reich, a w przygotowaniu sa przekłady Aesthetics, t. 1 i 2, Morality and the Knowledge of Ethical Values (rozprawa habilitacyjna) oraz Metaphysics and Community. Jak widać z powyższych zestawień, dzieła Hildebranda są również sukcesywnie tłumaczone na język polski.

2 Zob. <http://www.hildebrandproject.org> (dostęp: 6.03.2016). 


\section{Wartości w koncepcii Hildebranda}

Jednym z głównych źródeł koncepcji Hildebranda była tradycja fenomenologii realistycznej, w nurcie której młody filozof zdobywał swoją formację intelektualną. Wiązała się ona z pierwszą fazą ruchu fenomenologicznego, której początek wyznaczała publikacja Badań logicznych Husserla (1900/01). W tym okresie wielu studentów uniwersytetu monachijskiego, w tym Dietrich von Hildebrand, za radą Theodora Lippsa przeniosło się do Getyngi, by słychać wykładów Husserla. Badania logiczne były polemiką z pozytywizmem i relatywizmem oraz subiektywistycznym psychologizmem, którego rozkwit przypadał na drugą połowę XIX wieku. Głosiły one hasło "powrotu do rzeczy samych w sobie", takich, jakimi jawią się nam one w doświadczeniu; były zatem odwrotem od idealizmu w stronę obiektywizmu. $\mathrm{Na}$ powyższych założeniach metodologicznych oparte były prace fenomenologów tzw. koła monachijskiego, takich jak Max Scheler, Adolf Reinach, Alexander Pfänder i Moritz Geiger. Gdy Husserl w 1913 roku opublikował Ideen zu einer reinen Phänomenologie und phänomenologischen Philosophie ${ }^{3}$, które wyznaczały jego zwrot ku fenomenologii transcendentalnej, zajmującej się głównie zjawiskami świadomości, fenomenolodzy monachijscy nie poszli za jego przykładem i nadal rozwijali nurt fenomenologii realistycznej ${ }^{4}$.

Należący do ich grona Dietrich von Hildebrand już w swojej pracy habilitacyjnej Sittlichkeit und ethische Werterkenntnis, opublikowanej w roku 1922, opowiedział się za obiektywnym istnieniem wartości. Temat ten, przewijający się przez całą jego twórczość, doczekał się bardziej wyczerpującej eksploracji w klasycznym dziele Ethics z 1953 roku.

Punktem wyjścia analiz Hildebranda jest pojęcie ważności czy też doniosłości, które oznacza, że dany przedmiot staje się nam nieobojętny, że może motywować naszą wolę lub odpowiedzi afektywne ${ }^{5}$. W tym kontekście wartość rozumiana jest jako jedna z trzech kategorii ważności, skontrastowana $\mathrm{z}$ dwiema pozostałymi, czyli z kategorią obiektywnego dobra dla osoby oraz kategorią tego, co subiektywnie

3 Por. E. Husserl, Idee czystej fenomenologii i fenomenologicznej filozofii, t. 1, przeł. D. Gierulanka, Warszawa 1967.

4 Por. np. J. Seifert, Introductory Essay, w: D. von Hildebrand, What Is Philosophy?, New York 1991.

5 Por. D. von Hildebrand, Ethics, Chicago 1953, s. 24. 
zadowalające. Wartość oznacza to, co jest ważne samo w sobie, co $\mathrm{z}$ tej racji domaga się naszej odpowiedzi. Odpowiadając na wartość, osoba przekracza samą siebie i tym samym się rozwija. Życie odpowiedzią na wartość jest życiem moralnym w sensie ścisłym.

Natomiast to, co subiektywnie satysfakcjonujące (np. zapalenie papierosa), nie posiada ważności samo w sobie, posiada ją jedynie w odniesieniu do naszej przyjemności. Osoba poprzestając na tym, co subiektywnie satysfakcjonujące, pozostaje zamknięta w kręgu własnego egocentryzmu. Redukcja życia do tego poziomu jest wyrazem hedonizmu lub pewnej postaci utylitaryzmu.

Trzecią istotną kategorią doniosłości jest obiektywne dobro dla osoby, które polega na prowadzeniu do dobrostanu i szczęścia. Dążenie do obiektywnego dobra dla osoby jest, zdaniem Hildebranda, uzasadnione podmiotowym charakterem człowieka i związkiem tego dobra z godnością człowieka jako osoby. Dążenie do dobra dla osoby odpowiada poziomowi etyki eudajmonistycznej. Jeśli chodzi o relację pomiędzy wartością a obiektywnym dobrem dla osoby, w życiu moralnym konieczne jest uwzględnienie obydwu tych kategorii ważności. Negacja odpowiedzi na wartość skutkuje bowiem sprowadzeniem człowieka do sfery biologicznej, zaś negacja obiektywnego dobra dla osoby - pozbawieniem jej podmiotowości i charakteru osobowego ${ }^{6}$.

W sferze wartości można $\mathrm{z}$ kolei wyróżnić dwa zasadnicze ich rodzaje: wartości ontyczne oraz wartości jakościowe. Różni je między innymi fakt, że wartości jakościowe posiadają odpowiadające im antywartości, zaś w dziedzinie wartości ontycznych nie mamy do czynienia $z$ antywartościami. Poza tym wartości ontyczne w znacznie większym stopniu są jednoznacznie powiązane ze swoim nosicielem, zaś wartości jakościowe mogą być rozpatrywane w oderwaniu od niego. Hierarchia wartości ontycznych odpowiada hierarchii bytów. $\mathrm{Na}$ samym dole hierarchii bytowej Hildebrand umieszczał sferę materii, nad nią sferę witalną, którą z kolei znacznie przewyższa sfera osoby duchowej. Na samym szczycie umieszczał natomiast sferę nadprzyrodzoną, sferę bytu absolutnego i nieskończonego.

W obrębie wartości jakościowych można natomiast wyróżnić poszczególne rodziny, czy też dziedziny wartości, które posiadają

6 Por. D. von Hildebrand, Kategorie ważności, w: Z fenomenologii wartości, red. i przekł. W. Galewicz, Kraków 1988, s. 131-160; por. np. J. Galarowicz, Fenomenologiczna etyka wartości, Kraków 1997, s. 244nn. 
wspólny temat. Główne rodziny wartości tworzą wartości moralne, intelektualne i estetyczne. Pomiędzy wartościami moralnymi, takimi jak hojność, pokora, czystość, sprawiedliwość i miłość występuje szczególne pokrewieństwo. Podobnie dzieje się w przypadku wartości intelektualnych, do których należą intelektualna przenikliwość, dowcip, głębia, błyskotliwość. Wartości estetyczne skupione wokół naczelnej wartości piękna obejmują wdzięk, majestat, wzniosłość.

W obrębie danej rodziny wartości cechują się porządkiem hierarchicznym, np. pokora ma rangę wyższą niż odpowiedzialność. Jeszcze większe różnice występują pomiędzy poszczególnymi rodzinami wartości, gdyż są one wyznaczane przez różne tematy. Wśród wartości naturalnych najwyższym dobrem są wartości moralne ${ }^{7}$. Cechą wyróżniającą wartości moralne jest ich konieczny związek z osobą, jej działaniem lub postawą. Co więcej, wiążą się one z odpowiedzialnością człowieka, a tym samym zakładają jego wolność, cechują się też szczególną powagą. Wartości moralne są przedmiotem ocen sumienia, są wreszcie niezbędne każdemu człowiekowi. Kolejną ich cechą jest fakt, że domagają się nagrody, antywartości moralne zaś kary. Wreszcie sfera wartości moralnych jest uprzywilejowanym pomostem pomiędzy światem wartości naturalnych i nadprzyrodzonych. Wszystkie wartości wskazują na Boga, który jest źródłem i pełnią wartości. W najwyższym i najściślejszym sensie dotyczy to wartości nadprzyrodzonych, „moralności świętych”.

\section{Cnota w koncepcii Hildebranda}

Człowiek posiada zdolność do przekraczania siebie. Wykraczanie poza własny egocentryzm, dokonujące się w relacji do wartości moralnych, stanowi kluczowy warunek rozwoju moralnego człowieka. Relacja osoby do wartości ma trzy kolejne stopnie: percepcja wartości, bycie

7 Por. D. von Hildebrand, Ethics, dz.cyt., rozdz. 10: „Ontological and Qualitative Values", s. 129-139. Ewolucję stanowiska Hildebranda w kwestii klasyfikacji wartości w klarowny sposób przedstawił Leszek Kopciuch. Por. tenże, Wolność a wartości. Max Scheler, Nicolai Hartmann, Dietrich von Hildebrand, Hans Reiner, Lublin 2010, s. 101-110. Wskazał on na modyfikacje wprowadzone w zbiorze Moralia w stosunku do Ethics, takie jak dodanie norm, autorytetu i prawa do kategorii tego, co ważne same w sobie (do której należą wartości).

8 Por. D. von Hildebrand, Ethics, dz. cyt., rozdz. 14: „God and Values”, s. 161166 oraz rozdz. 15: „The Nature of Moral Values”, s. 169-179. 
poruszonym przez wartość oraz odpowiedź na wartość ${ }^{9}$. Odpowiedź ta może się realizować w trzech różnych sferach życia moralnego: w sferze czynów, w sferze odpowiedzi wolicjonalnych i afektywnych oraz w sferze cnót. Sfera cnót jest zatem jedną z fundamentalnych sfer moralności, obejmującą trwałe cechy charakteru człowieka. Hildebrand stwierdza wręcz, że stanowi ona centrum i szczyt moralności ${ }^{10}$.

$\mathrm{Na}$ czym zatem polega istota cnoty? Posiada ona własną wartość moralną, niesprowadzalną do sfery czynów lub odpowiedzi afektywnych. A zatem nie jest tylko dyspozycją do moralnie słusznego działania czy też potencjalnością pojedynczych działań lub odpowiedzi, ale cechą charakteru zaktualizowaną w osobie.

Podstawą cnoty (np. miłości lub nadziei) jest ponadaktualna odpowiedź na wartość. Ponadaktualność oznacza, że dane nastawienie trwa w głębi osoby nawet wówczas, gdy świadomie koncentruje się ona na czymś innym. Dobra intencja nie utożsamia się cnotą, podobnie jak dążenie do cnoty nie jest równoznaczne $z$ jej posiadaniem. Aby tak się stało, intencja ta musi przeniknąć całą osobowość człowieka. W ten sposób cnota staje się jego drugą naturą, inaczej mówiąc, przybiera charakter habitualny. Na przykład człowiek hojny postępuje zawsze w sposób hojny. Działanie takie nie wymaga od niego wielkiego wysiłku, przeciwnie, możliwość przyjścia innym z pomocą jest dla niego źródłem radości, co uzewnętrznia się w jego zachowaniu i wyglądzie ${ }^{11}$.

Rozumienie cnoty jako sprawności czy też uzdolnienia domaga się wprowadzenia pewnych rozróżnień. Hildebrand zaznacza, że nie jest ona po prostu zdolnością chcenia, poznawania, odczuwania ani umiejętnością (jak gra w tenisa) czy też elementem temperamentu (jak flegmatyczność). W przeciwieństwie do cnót, cechy temperamentu nie mają charakteru intencjonalnego, nie niosą ze sobą poznania dobra ani odpowiedzi na nie. $Z$ drugiej strony, dany temperament może ułatwiać zdobywanie jednych cnót, a utrudniać dążenie do innych. Dla przykładu z temperamentem cholerycznym łatwiej idzie w parze cnota odwagi niż łagodności ${ }^{12}$.

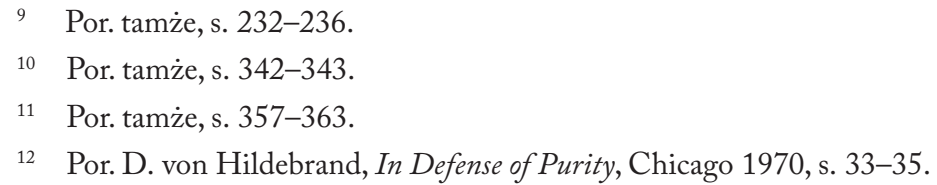


Hildebrand wyróżnia szersze i węższe znaczenie cnoty. W znaczeniu szerszym mieści się cnota wynikająca $\mathrm{z}$ usposobienia (dispositional virtue), która ma charakter nieświadomy, akcydentalny. Natomiast cnota w sensie ścisłym występuje u człowieka moralnie świadomego - jest oparta na dostrzeżeniu i zrozumieniu wartości oraz zakorzeniona w sferze duchowej.

Cnota odróżnia się także od innych trwałych cech człowieka, takich jak np. techniczna umiejętność (np. prowadzenie samochodu, mówienie w obcym języku) lub przyzwyczajenie. Zdolność do wyrobienia $\mathrm{w}$ sobie adaptacyjnych nawyków jest cenna, ale zasadniczo należy do sfery biologicznej. Różnica polega na tym, że łatwość działania płynąca $z$ cnoty jest motywowana wartością, a nie przyzwyczajeniem. Jest więc zawsze działaniem świadomym i wolnym. Działanie zaś w sensie ścisłym nie sprowadza się nigdy do umiejętności lub techniki. Przyzwyczajenie w tym kontekście może sprowadzać zagrożenie rutyną, np. w kontakcie $\mathrm{z}$ wysokimi wartościami. $Z$ drugiej strony, nawyki (np. wczesne wstawanie rano), jakkolwiek nie są zasadnicze dla zdobycia cnoty, mogą być pomocne. Przyzwyczajenie powstałe w wyniku długiego obcowania $\mathrm{z}$ przedmiotem umożliwia jego głębsze poznanie, a tym samym prawdziwą relację z nim. Przyzwyczajenie, które samo $\mathrm{w}$ sobie jest czynnikiem pozamoralnym, może być wsparciem $\mathrm{w}$ procesie budowania cnoty. Poza tym, w nabywaniu cnót istotna jest rola czasu i konsekwentnej praktyki. O ile jednak nawyk ma charakter mechaniczny, to cnota ma charakter organiczny ${ }^{13}$.

Wygłoszone w latach trzydziestych pogadanki radiowe Hildebranda na temat cnót, które stały się pierwowzorem książki Sittliche Grundhaltungen, spotkały się z żywym przyjęciem słuchaczy. Ich treść - spisana i udostępniona także polskim czytelnikom - nie straciła nic ze swej aktualności.

Pierwszą omówioną w nich fundamentalną postawą wobec rzeczywistości jest postawa szacunku (reverence). Hildebrand uznaje ją za istotny aspekt podziwu $(\theta \alpha \nu \mu \alpha ́ \zeta \varepsilon l v$, thaumadzein), wskazywanego przez Platona i Arystotelesa jako początek filozofiii ${ }^{14}$. Cześć determinuje stosunek do rzeczywistości, do świata, i stanowi niezbędny wa-

13 Por. D. von Hildebrand, Ethics, dz. cyt., s. 366-378.

14 Por. D. von Hildebrand, The Role of Reverence in Education, w: tenże, The New Tower of Babel, London 1954, s. 167. 
runek dostrzegania wartości oraz adekwatnego odpowiadania na nie. Przeciwieństwem szacunku jest arogancja, egocentryzm, manipulacja oraz podejście instrumentalne ${ }^{15}$.

Kolejną podstawową postawą moralną jest wierność, która stanowi warunek moralnego rozwoju osoby oraz fundament samowychowania, a także jest aspektem dojrzałej odpowiedzi na wartości. Postawą komplementarną do wierności jest odpowiedzialność. Zdaniem Hildebranda, kształtowanie poczucia odpowiedzialności powinno być jednym z głównych celów wszelkiego rozumnego wychowania oraz kształtowania charakteru i odpowiedzialności ${ }^{16}$.

Przekonaniu o istnieniu i poznawalności obiektywnej rzeczywistości towarzyszy poszanowanie prawdy, będące podstawą autentyczności oraz warunkiem powodzenia wszelkich działań edukacyjnych. Omawiany katalog postaw moralnych zamyka dobroć, która odbija całą sferę wartości w osobie ludzkiej, a tym samym może być uznana za serce moralności i „królową cnót” ${ }^{17}$.

Istotnym źródłem moralnego rozwoju może być również doświadczenie religijne. We wstępie do swojej Etyki Hildebrand wskazuje, że doświadczenia chrześcijańskiego, którego szczytową formę można odnaleźć w życiu świętych, nie należy arbitralnie wykluczać z zakresu filozoficznych dociekań, gdyż należy ono do dziedziny tego, co dane ${ }^{18}$. Postawy i dążenia, wynikające $\mathrm{z}$ analizy doświadczenia chrześcijańskiego, omawia Hildebrand w traktacie Przemienienie w Chrystusie. Podstawową tezą tej książki jest to, że życie nadprzyrodzone wpływa na etos osoby, że prowadzi do jej wewnętrznej przemiany. Hildebrand szczegółowo analizuje warunki, aspekty i etapy owego moralnego przeobrażenia. Wnikliwie opisuje typowo chrześcijańskie cnoty, takie jak: gotowość przemiany, skruchę, poznanie siebie samego, prawdziwą świadomość, prawdziwą prostotę, skupienie i kontemplację, pokorę, ufność w Bogu, cierpliwość, pokój, miłosierdzie ${ }^{19}$.

15 Por. D. i A. von Hildebrand, Sztuka życia, przeł. G. Grygiel, Poznań 2002, s. 13-23.

16 Por. tamże, s. 27-52.

17 Por. tamże, s. 53-76.

18 Por. D. von Hildebrand, Ethics, dz. cyt., s. 18-19.

19 Por. D. von Hildebrand, Przemienienie w Chrystusie, przeł. J. Zychowicz, Kraków 1982, s. 372. 


\section{Pedagogiczne znaczenie koncepcii Hildebranda}

Hildebrand podejmuje kwestię autonomii pedagogiki oraz współzależności pomiędzy etyką a pedagogiką w artykule Gibt es eine Eigengesetzlichkeit der Pädagogik? (Czy istnieje autonomia pedagogiki?) $)^{20}$. Definiuje w nim cel wychowania jako realizację wszelkich wartości osobowych w wychowanku, zarówno witalnych, estetycznych, intelektualnych, przede wszystkim zaś moralnych, ostatecznie zaś prowadzenie go do zbawienia ${ }^{21}$. Zauważa dalej, że działania wychowawcze są ukierunkowane na cel, którym jest pewien ideał osobowości. Z obserwacji tej wynika wniosek, że $z$ racji zakorzenienia wychowania w wartości osoby nie da się budować pedagogiki w izolacji od założeń antropologiczno-etycznych ${ }^{22}$.

Jakie zatem pedagogiczne wnioski wypływają z przedstawionej wyżej koncepcji etycznej? Hildebrand sam podsuwa odpowiedź na to pytanie:

Dla pedagoga jednym z głównych sposobów wychowania moralnego jest wystawianie dusz swoich uczniów na działanie wartości. W każdym dążeniu do rozwoju moralnego i religijnego to otwarcie duszy odgrywa kluczową rolę 23 .

$\mathrm{Z}$ drugiej strony wartości nie mogą być traktowane jako środek do celu, nawet jeżeli celem tym miałoby być moralne udoskonalenie człowieka:

Najgłębsze oddziaływanie pedagogiczne jest zastrzeżone dla tego, czego nie zastosowano jako środka pedagogicznego, dla tego, czego sens jest niezależny od oddziaływania pedagogicznego i co w swym bogactwie udziela tego działania jako superfluum, daru obfitości ${ }^{24}$.

To zastrzeżenie Hildebranda jest fundamentalne dla jego koncepcji. Wynika ono z odrzucenia podejścia utylitarystycznego, in-

20 Por. D. von Hildebrand, Gibt es eine Eigengesetzlichkeit der Pädagogik?, w: tenże, Die Menschheit am Scheideweg, Regensburg 1955, s. 158-187.

21 Por. tamże, s. 176-177.

22 Por. tamże, s. 182.

23 D. von Hildebrand, Ethics, dz. cyt., s. 210.

24 D. von Hildebrand, Liturgia i osobowość, przeł. M. Grabowska, Kraków 2014, s. 22. 
strumentalnego, a nawet eudajmonistycznego, które sens ludzkiego działania upatruje w dążeniu do własnego obiektywnego dobra eudajmonii. Jest to egzemplifikacja bardziej uniwersalnej zasady: najgłębsza przemiana człowieka jest niejako skutkiem ubocznym odpowiedzi na wartość, czyli zaangażowania się w rzeczywistość ze względu na nią samą, czemu towarzyszy zapomnienie o sobie. Poddanie się fascynacji wartości w postawie kontemplacyjnej, także w znaczeniu kontemplacji naturalnej, można opisać inaczej jako postawę frui, bezinteresownego skupienia się na wartości, dzięki któremu wartość przenika nas i dokonuje się w nas wewnętrzna przemiana ${ }^{25}$.

Dążenie do postawy kontemplacyjnej jest zdaniem Hildebranda szczególnie istotne w przypadku zawodów, które odnoszą się do dóbr o wysokiej wartości wewnętrznej:

Praca artysty, filozofa, nauczyciela wymaga postawy kontemplacyjnej jako niezbędnego warunku dla głębi i wewnętrznej pełni wszelkiej działalności dotyczącej dóbr cechujących się wysokimi wartościami. Musimy otrzymywać, abyśmy byli zdolni do dawania. Nasza dusza musi zostać zapłodniona, aby zrodzić rzeczy wielkie i ważne ${ }^{26}$.

Istotnie, trudno sobie wyobrazić konfrontowanie wychowanków ze światem wartości, jeśli relacja samego wychowawcy ze sferą wartości byłaby tylko powierzchowna. Wydaje się, że brak postawy kontemplacyjnej, która jest warunkiem otwartości na rzeczywistość w jej głębszym wymiarze, może również prowadzić do syndromu wypalenia zawodowego, do poczucia frustracji czy własnej nieadekwatności wobec napotykanych wyzwań.

$Z$ faktu, że praca nauczycieli i pedagogów oparta jest na relacji z uczniami płyną specyficzne wymogi moralne. Jako szczególnie cenione cechy w tym zawodzie Hildebrand wymienia: miłość, cierpliwość, inteligencję, zdolność rozumienia drugiego człowieka, ale także stanowczość i sprawiedliwość ${ }^{7}$. Jeśli chodzi metody perswazji i wywierania wpływu, zdecydowanie preferuje te, które apelują do wolnego i rozumnego centrum osoby, krytykuje natomiast metody

25 Por. D. von Hildebrand, Przemienienie w Chrystusie, dz. cyt., s. 174-175.

26 Tamże, s. 236-237.

27 Por. D. von Hildebrand, Efficiency and Holiness w: tenże, The New Tower of Babel, dz. cyt., s. 215. 
manipulacyjne oparte jedynie na sferze witalnej (jak np. propaganda nacjonalistyczna czy kult Führera) ${ }^{28}$.

Współczesna pedagogika podkreśla upodmiotowienie i spersonalizowanie procesu uczenia. Także $\mathrm{w}$ tej perspektywie mogą być pomocne przeprowadzone przez Hildebranda fenomenologiczne opisy postaw i dążeń, sprzyjających osobowemu, moralnemu i religijnemu rozwojowi człowieka. Np. pisząc o pracy nad sobą zwraca on uwagę na fakt, że rozwój cnót wiąże się z powtarzaniem konkretnych decyzji, czynów i zachowań29 ${ }^{29}$ co jest zgodne z arystotelesowską tradycją aretologiczną. Warto równocześnie dodać, że zdaniem Hildebranda także posłuszeństwo prawowitemu autorytetowi praktycznemu, którego pierwowzorem jest władza rodzicielska, jest moralnie zobowiązujące i tym samym posiada istotne znaczenie wychowawcze ${ }^{30}$.

\section{Zakończenie}

Przedstawiona w artykule koncepcja aksjologiczna, łącząca etykę ogólną ze szczegółową, jest - jak sądzę - warta przemyślenia i dyskusji. Biorąc pod uwagę powyższe rozważania dotyczące ponadczasowego charakteru fundamentalnych zagadnień obiektywności wartości, można bowiem postawić tezę, że relacja pedagogiczna nigdy nie jest aksjologicznie neutralna. Co najwyżej pedagog może opierać się na swoich antropologiczno-etycznych założeniach w sposób bezrefleksyjny. Świadomość własnych założeń aksjologicznych i otwarte ich komunikowanie wydaje się być ważnym wymiarem rozwoju zarówno osobistego, jak i zawodowego pedagoga; jest też wyrazem uczciwości wobec uczniów i podopiecznych.

\section{BIBLIOGRAFIA}

Galarowicz J., Fenomenologiczna etyka wartości, PAT, Kraków 1997.

Hildebrand Project, <http://www.hildebrandproject.org> (dostęp: 6.03.2016). Hildebrand von A. i D., Sztuka życia, przeł. G. Grygiel, Klub Książki Katolickiej, Poznań 2002.

28 Por. D. von Hildebrand, Legitime und illegitime Formen der Beeinflussung, w: tenże, Die Menschheit am Scheideweg, Regensburg 1955, s. 355-405.

29 Por. D. von Hildebrand, Przemienienie w Chrystusie, dz. cyt., s. 169.

30 Por.D. von Hildebrand, Moralia, Regensburg 1980, s. 145-148; por. tenże, Das Wesen der echten Autorität, w: tenże, Die Menschheit am Scheiderweg, dz. cyt., s. 341-354. 
Hildebrand von D., Das Wesen der echten Autorität, w: tenże, Die Menschheit am Scheideweg, Verlag Josef Habbel, Regensburg 1955.

Hildebrand von D., Efficiency and Holiness, w: tenże, The New Tower of Babel, Burns \& Oates, London 1954.

Hildebrand von D., Ethics, Franciscan Herald Press, Chicago 1953.

Hildebrand von D., Gibt es eine Eigengesetzlichkeit der Pädagogik?, w: tenże, Die Menschheit am Scheiderweg, Verlag Josef Habbel, Regensburg 1955.

Hildebrand von D., In Defense of Purity, Franciscan Herald Press, Chicago 1970.

Hildebrand von D., Kategorie ważności, w: Z fenomenologii wartości, red. i przekł. W. Galewicz, PAT, Kraków 1988.

Hildebrand von D., Legitime und illegitime Formen der Beeinflussung, w: tenże, Die Menschheit am Scheideweg, Verlag Josef Habbel, Regensburg 1955.

Hildebrand von D., Liturgia i osobowość, przeł. M. Grabowska, Fundacja Dominikański Ośrodek Liturgiczny, Wydawnictwo M, Kraków 2014.

Hildebrand von D., Moralia, Verlag Josef Habbel, Regensburg 1980.

Hildebrand von D., Przemienienie w Chrystusie, przeł. J. Zychowicz, Znak, Kraków 1982.

Hildebrand von D., The Role of Reverence in Education, w: tenże, The New Tower of Babel, Burns \& Oates, London 1954.

Husserl E., Idee czystej fenomenologii i fenomenologicznej filozofii, t. 1, przeł. D. Gierulanka, PWN, Warszawa 1967.

Kopciuch J., Wolność a wartości. Max Scheler, Nicolai Hartmann, Dietrich von Hildebrand, Hans Reiner, Wydawnictwo UMCS, Lublin 2010.

Molesztak A., Tchorzewski A., Wołoszyn W., W kregu wartości moralnych nauczyciela, WSP TWP, Warszawa 1996.

Seifert J., Introductory Essay, w: Dietrich von Hildebrand, What Is Philosophy?, Routledge, New York 1991.

\section{ADRES DO KORESPONDENCJI:}

Dr Paweł Kaźmierczak

Akademia Ignatianum w Krakowie

e-mail:pawkaz@interia.pl 